\title{
EchoGéo
}

$56 \mid 2021$

Les dynamiques spatiales contemporaines de la Russie

\section{Unequal and Asymmetric Internationalisation of Large Russian Cities}

Insights from the Internationalisation Ranking

\section{Ekaterina Mikhailova}

\section{(2) OpenEdition \\ Journals}

\section{Electronic version}

URL: https://journals.openedition.org/echogeo/21919

DOI: 10.4000/echogeo.21919

ISSN: 1963-1197

\section{Publisher}

Pôle de recherche pour l'organisation et la diffusion de l'information géographique (CNRS UMR 8586)

\section{Electronic reference}

Ekaterina Mikhailova, "Unequal and Asymmetric Internationalisation of Large Russian Cities", EchoGéo [Online], 56 | 2021, Online since 25 June 2021, connection on 03 August 2021. URL: http:// journals.openedition.org/echogeo/21919; DOl: https://doi.org/10.4000/echogeo.21919

This text was automatically generated on 3 August 2021.

EchoGéo est mis à disposition selon les termes de la licence Creative Commons Attribution - Pas d'Utilisation Commerciale - Pas de Modification 4.0 International (CC BY-NC-ND) 


\title{
Unequal and Asymmetric Internationalisation of Large Russian Cities
}

\author{
Insights from the Internationalisation Ranking
}

\author{
Ekaterina Mikhailova
}

The author is grateful to Prof. Vladimir Kolossov for discussions and advice on this study and to Yana Rudneva, then a third-year student of Faculty of Geography, Lomonosov Moscow State University, for her contribution to the data collection.

12021 marks 30 years since the dissolution of the Soviet Union and Russia's reintegration into the globalising world. To what extent has Russia become internationalised? How international are large Russian cities? What economic, political and symbolic capital have Russian cities derived from their transnational connections and external ties? This study aspires to address these questions by revealing international actions that take place among and within Russian regional capitals.

2 The paper has six sections. The first explores the transformations that cities have undergone in globalisation. The second section reviews studies measuring the involvement of Russian cities in globalisation processes. The third section explains the methodology of the study. The fourth presents the ranking results. The fifth section discusses the ranking results in the context of the previous studies. The final section recapitulates the findings and concludes with policy recommendations.

Before embarking on the analysis, we should set down our understanding first of what it takes for an urban entity to be considered a 'city' and second for a Russian city to be considered large. So far as the first requirement is concerned, this study has adopted the definition recommended by the UN Statistical Commission $(2020$, p. 6), i.e. a city is understood as an urban entity with a population of at least 50,000 inhabitants in contiguous $1 \mathrm{~km}^{2}$ population grid (>1,500 inhabitants per $\mathrm{km}^{2}$ ). Second, the indicator figure for defining a large Russian city has been set at 600,000 inhabitants. 


\section{Empowerment of Cities in Globalisation}

4 Contemporary understanding of economic globalisation is tightly intertwined with the notion of a world city network within a global space of flows developed in the seminal works of M. Castells (1996), J. Friedmann (1986), P. Knox and P. Taylor (1995), S. Sassen (1991) and others. These studies interpret major cities (termed "world cities" by Friedmann or "global cities" by Sassen) as the key nodes of the world economy and leading post-industrial urban centres that draw much of their development opportunities from interactions in transnational urban networks. Applying the world cities approach to studying other cities allowed urban scholars to conclude that "the organising force of economic activity" has been shifting "from space and size to network and centrality" (Neal, 2011, p. 68).

5 Several studies have explored the gradual restructuring of macro-regional and national urban systems under the pressure of globalisation and their increasing embeddedness into the global economy. Taylor and Derudder conclude that European cities are "highly cosmopolitan in their intercity relations" (2004, p. 536) and often network with major world cities in other world regions. This finding has been confirmed by Van der Knaap and Wall (2005) whose study of European business-city relations within the world urban network brings out the fact that $50 \%$ of business-city connections in Europe in 2005 were extra-European. Based on the network analysis of multinational firms' ownership, Rozenblat (2018) concludes that European cities (along with their North American counterparts) are at the core of the world urban network.

6 Shin and Timberlake (2000) illustrate the changing place of Asian cities in the world urban network by examining airline travel among 100 world cities in 1975-1997. The authors conclude that the share of passengers travelling to world cities in Asia has grown from $15 \%$ in 1977 to $33 \%$ in 1997 of total world city airline traffic, testifying to the increasing centrality of Asian world cities. More recently, a comparative study of Derudder and co-authors comparing the levels of cities' network connectivity in 2010 and 2016 - understood as cities' integration in the office networks of producer services firms - has concluded that the level of connectivity is rising in Pacific Asian cities in general and Chinese cities in particular (Derudder et al., 2018, p. 193).

7 Moving to North America, Neal has demonstrated that in the 20th century the US urban hierarchy has shifted from "a size-based central place-like structure to being relationally structured around urban networks" (2011, p. 68). Using data on population size, economic structure and airline passenger traffic of 64 metropolitan areas in the US from 1900 to 2000, Neal shows that some large cities have failed to secure a central position in the contemporary urban network.

8 In addition to economic globalisation, political globalisation, notably the growing involvement of sub-national actors in international affairs (Duchacek, 1987; Keating, 1999; Tavares, 2016) has greatly contributed to the empowerment of cities worldwide. The pressure to engage on the international arena combined with the accelerating territorial competition has presented cities with a dilemma "to internationalise or to perish" (Soldatos, 1991). In response to this dilemma, many cities plunged into city diplomacy. The first wave of widespread local governments' international activities occurred after World War II via reconciliation-driven twinning agreements (Zelinsky, 1991; Van der Pluijm et Melissen, 2007). More recently, the most global, vocal and efficient form of cities' international actions has become participation in city networks 
(Acuto et Leffel, 2020). Over the last three decades, the number of inter-city partnerships and international city networks has increased dramatically and motives behind these partnerships have moved beyond just cultural exchange (Jayne et al., 2011). More and more cities cooperate to acquire mutual economic gains and coordinate joint actions to withstand current societal challenges such as economic and social inequalities, migration, violent extremism, pandemics, etc.

9 Admitting the strengthening interconnection between the local and the global (Castells, 2002; Herod, 2003) and between urbanisation and globalisation (Brenner, 1999; Sigler, 2016), it is fair to say that sooner or later the challenge of economic and political internationalisation confronts every large contemporary city. As pinpointed in the introduction to the landmark edited volume "Cities in globalisation" (Taylor et al., 2007, p. 13-14), globalisation is pervasive and hence all cities today are to some degree "world cities" and "global cities" though the degree of their internationalisation varies greatly. Such socio-economic trends as the advent of the information age (Castells, 1996), the urban demographic transition (Dumont, 2018), the spread of urban entrepreneurialism (Brenner, 2009) and the devolution of power (Blank, 2010) have all helped globalise contemporary cities.

\section{Measuring Cities' Internationalisation in Russia}

The vast majority of studies addressing internationalisation focus on the transformations that occur either in higher education or in firms. In the former body of literature, it is common to interpret internationalisation as "the process of integrating an international, intercultural or global dimension into the purpose, functions or delivery of post-secondary education" (Knight, 2004, p. 25). In the second body of literature, internationalisation is seen as "an incremental process, wherein firms... increase commitment to international markets in a gradual, step-wise, manner through a series of evolutionary 'stages' " (Bell et al., 2003, p. 339). In the context of cities, internationalisation is usually understood as a process of cities acquiring and strengthening their international functions (see Corijn et al., 2009; Kolossov, Vendina et O'Loughlin, 2002; Kolossov et Eckert, 2007). As pointed by Rozenblat and Pumain, a city's capacity to perform international functions relies on its relative position in the national urban system as well as on the position of its country in international networks (2018, p. 128). How should we assess a city's internationalisation? Scholars have been examining this question in multiple variations for at least 35 years. By 2015 over 100 rankings of world cities and over 200 tools comparing city's globality have been developed (Ershova et Orlovskaya, 2018).

Despite the high number of studies examining the globalisation of individual cities (Kolossov, Vendina et O'Loughlin, 2002; Corijn et al., 2009) and sets of cities in particular countries and macro-regions (Timberlake et al., 2014; Derudder et al., 2018), the need for cross-national and intra-national studies of city's internationalisation is still quite acute for several reasons. First, as the integration of regional and national urban systems into the global economy is uneven, there is a need for assessing modes of national urban systems' involvement in globalisation processes (Rozenblat, 2018). Second, regions with large urban populations that joined globalisation processes relatively recently - such as post-socialist states - oftentimes require the adaptation of the Western-minded ranking tools. 
12 Russia's transition to a market economy in the early 1990s led to a polarization of country's spatial structure' with privileges concentrated in the largest cities - Moscow and St. Petersburg (Zubarevich, 2002; Kolossov et Eckert, 2007). Both have been instrumental to post-Soviet Russia's re-integration into the world economy. According to the most recent world-city rankings by the Globalisation and World Cities Research Network at Loughborough University (GaWC 2018; 2020), Moscow has invariably been assigned to the alpha group - "very important world cities that link major economic regions and states into the world economy", while St. Petersburg has fluctuated between categories of "gamma +" in 2018 and "beta -" in 2020.

13 Over time other large Russian cities also started integrating into global economic and political processes (Zotova 2007). However, the progress of their internationalisation has remained largely under-researched as the majority of international rankings of city globality do not include Russian cities beyond Moscow and St. Petersburg. It was not until 2018 that GaWC incorporated two more Russian cities - Kazan and Novosibirsk in the ranking and assigned them to the "Cities with sufficiency of services" group, i.e., not world cities yet but ones that are self-sufficient in services and not dependent on world cities.

14 Several studies (such as Kolossov et Eckert 2007; Ershova et Orlovskaya 2018) attempted to apply ranking techniques specifically adapted to large Russian cities. While Kolossov and Eckert's study (2007) focuses on the comparison of Yekaterinburg and Rostov-onDon, it also presents quantitative data comparing over 15 Russian regional capitals in terms of three indicators: the number of retail chains by origin and two measures of city's centrality - airways and railway communication. Importantly, Kolossov and Eckert (2007, p. 120-122) identify two country-specific variables determining the character and degree of Russian cities' international actions: first, political post-Soviet transformation and second the country's extreme geographical, sociocultural, ethnic and economic diversity.

15 Ershova and Orlovskaya (2018) constructed a typology of Russian cities with a population over one million based on two criteria: human development index (HDI) and the index of urban environment quality - an indicator that authors compared to the urban quality of life. Additionally, the authors analysed whether Russian megapolises have twinning agreements with world cities. However, this information has not been used in their typology.

16 A recent study by Rogov and Rozenblat (2020) assesses the integration of Russian cities into economic globalisation by looking at 'Large Urban Regions' (LUR) that allow capturing multinational corporations (MNCs) located in core-city hinterlands. The authors justify the importance of LURs for Russia by noting the socialist urban planning heritage whereby many large industrial and scientific satellite cities were built around core cities. Rogov and Rozenblat rank the 16 largest cities and their LURs in terms of the MNCs presence and demonstrate that a city's position in the national urban hierarchy often changes significantly if the LUR delineation is applied.

17 While these three publications contribute to understanding the pace of Russian cities' internationalisation, they do not provide a comprehensive picture due to the limited sample size and the number of criteria. To fill this gap, this paper tries to assess the internationalisation of large Russian cities in a broader way and reveal which of them have been more successful in developing their international functions, how and why. 


\section{Methodology}

18 This study has a predecessor conducted in 2007 by V. Kolosov and M. Zotova ${ }^{1}$ who ranked large Russian cities in terms of their involvement in international, supranational and transnational activities. While the sample and the indicators used in 2007 differ substantially from those used here ${ }^{2}$, the logics of these studies have important similarities. First, both studies approach large cities as both venues of international activities and as international actors in their own right. Second, both studies aim to capture a city's internationalisation through various manifestations - a city's official external ties, its level of internationalisation, the number of influential economic actors stationed in the city and amongst its residents.

19 This paper defines a city's internationalisation in terms of the broad range of activities that take place within the city and with the city as a crucial actor. A city's internationalisation leads to that city's higher involvement in global and regional political, economic and sociocultural processes and to its higher international visibility. A city's internationalisation is a multi-dimensional process that includes (at least) three components or frames: 1) institutional, 2) infrastructural and 3) business dimensions. The institutional frame is the organisational and legal setups of a city's external ties. The organisational setup includes both city structures responsible for external ties and actors representing foreign, macro-regional or international structures stationed in the city - diplomatic missions, headquarters and branches of regional and international governmental and non-governmental organizations, cultural missions and diaspora organisations. The legal setup comprises international agreements signed by local governments. The infrastructural frame consists of the hard and soft infrastructure necessary for international cooperation and multinational businesses such as congress halls, executive hotels, human resources experienced in catering to international clients and city's international marketing activities promoting it as an attractive place to visit, host an event or invest in. The business frame consists of the degree of internationalisation of economic actors that operate in the city and amongst a city's residents. The former is evident in accumulated foreign investments and multinational businesses located in the city - MNCs, international banks and hotel chains managed by international operators. The latter could be showcased by the businesses catering to outbound tourism - visa centres, tour operators specialised in outbound tourism and available direct international flights.

20 The empirical part of the study consisted of the six sequential stages: 1) sample formation; 2) definition of indicators; 3) database creation; 4) checks of the database; 5) ranking for each indicator; and 5) calculation of the integral ranking. Let us briefly discuss each stage.

21 The first three stages were conducted in 2017 at the Faculty of Geography, Lomonosov Moscow State University within a larger project "Urbocentric Model of the Spatial Organization of the World Economy" under direction of Prof. V. Kolossov and Prof. N. Sluka. The last three stages were redone in 2021.

22 As of January 1, 2020, there were 15 million-strong cities in Russia whose residents make up $23 \%$ of the country's population. However, Moscow and St. Petersburg, Russia's largest cities, take up half of this share (or $12.4 \%$ of Russia's population). Along with demographic leadership, these cities are clear leaders in internationalisation. To avoid asymmetry in the dataset, it was decided to focus on large Russian cities that are 
still "globalising" (Marcuse et van Kempen, 2000; McCann, 2004) rather than those already global. Hence, both Moscow and St. Petersburg were excluded from the sample.

The sample was then formed based on population size, administrative status and the spatial distribution of large Russian cities. The cities in the sample comprise cities that surpassed the threshold of 600,000 inhabitants by 2017. Assuming that regional capital status enhances internationalisation, large cities without such a status, namely Togliatti, the 19th largest Russian city, was excluded from the sample. To try to ensure balance in the spatial distribution of cities in the sample, among cities with over 600,000 inhabitants with regional capital status, those located in Siberia and the Russian Far East were preferred. Namely Barnaul, Khabarovsk and Vladivostok were chosen instead of Izhevsk, Ul'yanovsk and Yaroslavl, even though the latter three in 2017 had slightly larger populations than the selected cities.

The final sample included the following 20 cities (listed in the alphabetical order): Barnaul, Chelyabinsk, Irkutsk, Kazan, Khabarovsk, Krasnodar, Krasnoyarsk, Nizhny Novgorod, Novosibirsk, Omsk, Perm, Rostov-on-Don, Samara, Saratov, Tyumen, Ufa, Vladivostok, Volgograd, Voronezh and Yekaterinburg. As illustration 1 and table 1 shows, cities in the sample present six out of eight Russia's Federal Districts ${ }^{3}-$ all but the Northwestern and North Caucasian Federal Districts.

To grasp cities' multi-dimensional internationalisation, 13 indicators, each connected with one of the internationalisation frames, have been selected. Six indicators coincide with the 2007 study: the number of twinning and partnership agreements with foreign cities, the number of diplomatic missions, the number of foreign cultural missions, the number of international-class congress centres, the number of branches of MNCs and the number of branches of international banks ( $n^{\circ} 1-4$ and $n^{\circ} 8-9$ in table 2 ). The new or modified indicators include experience in hosting major international events (e.g., political summits, congresses, festivals, etc.), the number of visa centres, the number of executive-class hotels and of hotels managed by international operators (including foreign hotel chains and Russian hotel chains operating abroad by 2017), the volume of foreign-owned and jointly-owned property and the electronic internationalisation index.

The sources used for database creation are shown in table 2. Indicators as the number of twinning and partnership agreements with foreign cities, the number of diplomatic missions, the value of foreign-owned and jointly-owned property allowed direct data collection either from official statistics (namely the "Multistat" statistical portal) or from Internet resources including cities' official websites, webpages of city's international offices and official websites of territorial divisions of Russia's Ministry of Foreign Affairs.

By examining the official websites of cultural missions operating in Russia, six organisations with regional branches outside of Moscow and St. Petersburg have been revealed. They are Alliance Française, the Japan Centre, the Goethe Institute, the Jewish Agency for Israel (Sokhnut), the Yunus Emre Institute, and the Confucius Institute. Studying their websites enabled the identification of the number of foreign cultural missions in the cities in the sample.

Two indicators - the number of executive class hotels (4-5 stars) and the number of hotels managed by international operators - rely on the same sources: the two reports by Ernst and Young $(2016,2017)$ on international hotel brands operating in Russia. The 
information retrieved from these reports was checked on hotels' websites and the resultant information has been assembled in a thematic data set.

A similar logic has been used for identifying the number of branches of MNCs and branches of international banks in the cities in the sample: based on the list of 50 largest foreign companies operating in Russia as of 2016 prepared by Forbes (2017) and on the list of top 100 banks by assets operating in Russia as of 2016 prepared by Expert.ru (2017), the websites of MNCs and international banks were checked and a dataset with their regional offices was created.

Besides three indicators - the number of international-class congress centres and visa centres and experience in hosting major international events - have been filled in based on the Internet search. For the two former indicators, city maps, cities' official websites, regional and local mass media were of paramount importance. For the third indicator, both national and regional mass media and the cities' own official websites were the key sources.

31 To measure a city's electronic internationalisation index, a dedicated database has been compiled. This index was inspired by the index of electronic internationalisation of Russian universities, first calculated and released in 2015 by the Russian International Affairs Council (RIAC). To audit the content of English-language Internet resources of Russian universities, RIAC experts identified semantic blocks (such as "University Admission"; "University Educational Programmes"; "Foreign Partners" and others) and assessed their content, clearness and structure (Timofeev et al., 2016). In a similar vein, a city's electronic internationalisation index was designed to measure the comprehensiveness and quality of English-language content of its official Internet resources. This index is an aggregate of four rankings comparing a city's international online presence on the basis of criteria like the variety of its English-language website content, the frequency of website updates, scope and granularity of presented investment projects and the use of social media accounts (Facebook, Twitter and Vkontakte - regardless of the language of an account as some platforms have built-in translation function).

32 All but one indicator (i.e. 12 out of 13) allowed the preparing of indicator-specific rankings of 20 cities from the sample (see table 3). As a rule, if several cities got the same score, they were assigned with the same rank and the next rank was skipped. If cities did not have any asset relevant for the indicator (say, no diplomatic missions), they were assigned with the last (20th) rank. One indicator - experience in hosting major international events over the last 10 years $\left(n^{\circ} 7\right.$ in table 2$)$ - was used for collecting additional points that were awarded for each major international event hosted in the city. To calculate the total score, the 12 indicator-specific rankings were added up, and their sum then had the points awarded for indicator $n^{\circ} 7$ subtracted from it. For example, Yekaterinburg had a score of 28 points based on 12 indicatorspecific rankings. To calculate its final score, 3 points gained for the indicator $n^{\circ} 7$ were subtracted. Hence the final score of Yekaterinburg is 25 . The resulting score served as the basis for the integral ranking (see illustration 1, table 1 and table 3).

The indicators selected for this study resemble those used in other similar studies. For instance, Halbert et al. (2012) and a follow-up study by Rozenblat and Pumain (2018) used 25 indicators to classify European functional urban areas according to their economic development and international functions. In these studies, the indicators were arranged in six groups: territorial development, economic functions, political 
affairs, accessibility and transportation, cultural and tourist exchange and research and innovation. While the grouping of the indicators is more nuanced for the studies of European urban areas than for this study, it communicates the same message: international functions influence, and are evident in, all spheres of urban life. Several indicators used by Halbert et al. (2012) and Rozenblat and Pumain (2018) have direct analogues in the current study, e.g., the experience in hosting major international events in this study combines the two indicators in the two latter studies - the number of international fairs and the number of international congresses. The three studies have important differences too. For instance, this study focuses more on the infrastructure and less on its use (e.g., the number of the executive-class hotels in this study vs. the number of overnight stays in hotels in the two other studies) due to the fact that many large Russian cities are still at the stage of the infrastructure development. The studies of the European cities used several EU-related indicators (such as the number of EU lobbyists or the amount of the EU funds contributed to research projects) and many city-specific economic indicators (such as value added by activity). While the former indicators are not applicable in the Russian context, the latter have not been available due to the limitations of the Russian national statistics.

The present study has several limitations. First, the ranking method chosen for the study has been subject to criticism (Robinson, 2002; Akande et al., 2019; Wang 2019). The academic community is generally sceptical about the notion of comparability of ranked entities and quantification and aggregation procedures that can lead to simplification and content distortion. Second, the implementation of the method had several shortcomings. For instance, two indicator-specific rankings - the value of foreignowned and jointly-owned property - rely on the 2013 data: i.e. they show the degree of city's internationalisation three/four years earlier than the other 11 indicators. Besides, as the study was concluded in 2017 and summed up in an article only in 2021, some of its data are hard to verify today - particularly the degree of development of cities' official websites in English. Finally, some indicators that are traditionally used for assessing city's internationalisation - such as the value of foreign investment and foreign trade - were unavailable at city level, as the relevant data are typically collected and reported at the regional level in Russia. Taking these limitations into account, the paper offers the findings of the internationalisation ranking of large Russian cities to an English-speaking audience in the hope they will stimulate debates on, and new studies of, Russian regional capitals as international actors. 
Illustration 1 - Russian regional capitals included in the sample and their internationalisation rank

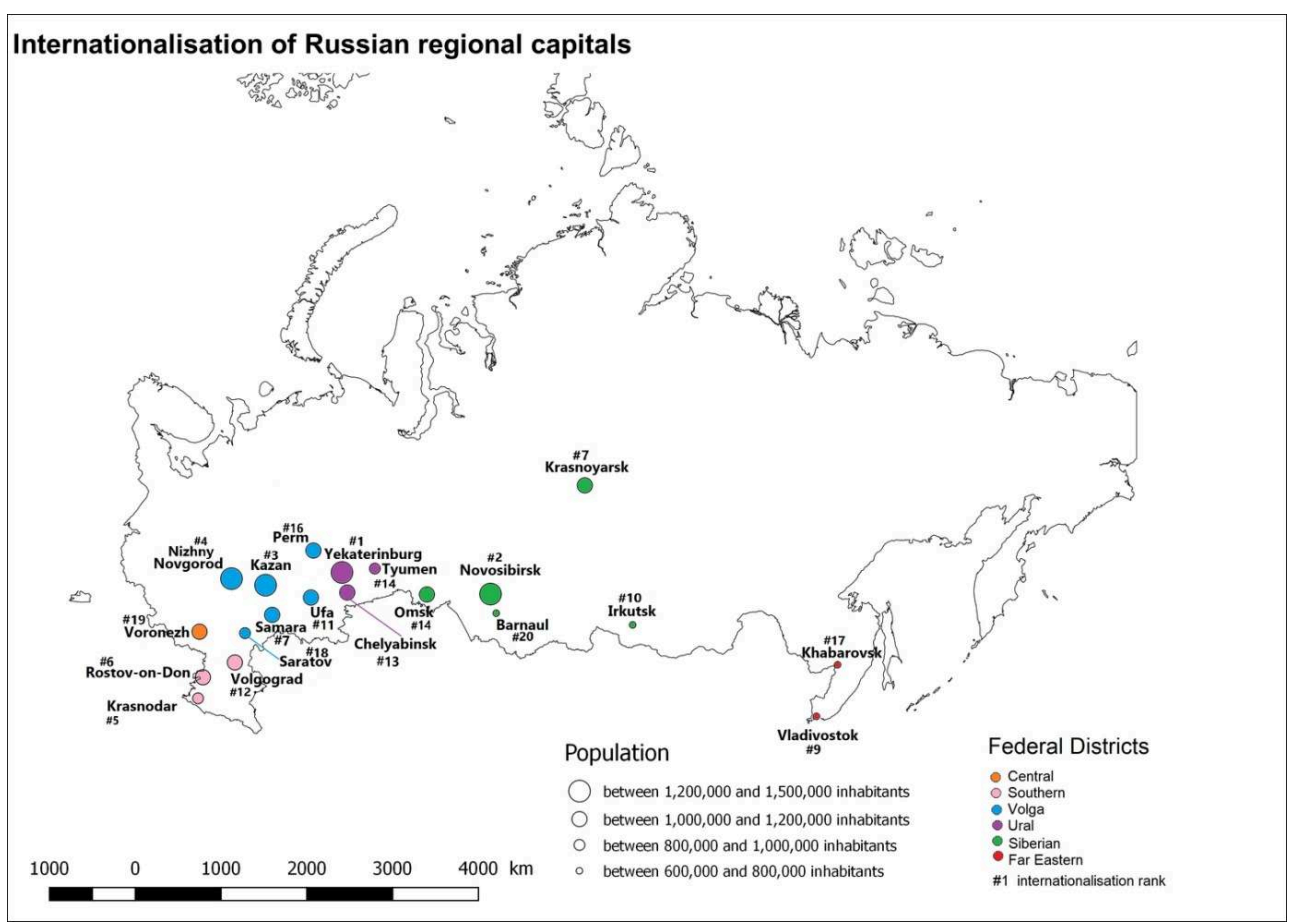

Author: E. Mikhailova.

Table 1 - Demographic characteristics of the sample

\begin{tabular}{|c|c|c|c|c|c|c|c|}
\hline \multirow{2}{*}{ Federal District } & \multirow{2}{*}{ City } & \multirow{2}{*}{ Region } & \multicolumn{2}{|c|}{ City's Population } & \multicolumn{2}{|c|}{ Share in region's population } & \multirow{2}{*}{$\begin{array}{c}\text { Integral } \\
\text { Internationalisation } \\
\text { Ranking } 2017\end{array}$} \\
\hline & & & 2017 & 2020 & 2017 & 2020 & \\
\hline Central & Voronezh & Voronezh Oblast & $1,039,801$ & $1,058,261$ & $44,52 \%$ & $45,53 \%$ & 19 \\
\hline \multirow{3}{*}{ Southern } & Rostov-on-Don & Rostov Oblast & $1,125,299$ & $1,137,904$ & $26,59 \%$ & $27,11 \%$ & 6 \\
\hline & Volgograd & Volgograd Oblast & $1,015,586$ & $1,008,998$ & $40,06 \%$ & $40,51 \%$ & 12 \\
\hline & Krasnodar & Krasnodar Krai & 881,476 & 932,629 & $15,82 \%$ & $16,43 \%$ & 5 \\
\hline \multirow{6}{*}{ Volga } & Nizhny Novgorod & Nizhny Novgorod Oblast & $1,261,666$ & $1,252,236$ & $38,85 \%$ & $39,10 \%$ & 4 \\
\hline & Kazan & Tatarstan & $1,231,878$ & $1,257,391$ & $31,71 \%$ & $32,22 \%$ & 3 \\
\hline & Samara & Samara Oblast & $1,169,719$ & $1,156,659$ & $36,51 \%$ & $36,38 \%$ & 7 \\
\hline & Ufa & Bashkortostan & $1,115,560$ & $1,128,787$ & $27,43 \%$ & $27,95 \%$ & 11 \\
\hline & Perm & Perm Krai & $1,048,005$ & $1,055,397$ & $39,82 \%$ & $40,60 \%$ & 16 \\
\hline & Saratov & Saratov Oblast & 845,300 & 838,042 & $34,10 \%$ & $34,60 \%$ & 18 \\
\hline \multirow{3}{*}{ Ural } & Yekaterinburg & Sverdlovsk Oblast & $1,455,514$ & $1,493,749$ & $33,62 \%$ & $34,65 \%$ & 1 \\
\hline & Chelyabinsk & Chelyabinsk Oblast & $1,198,858$ & $1,196,680$ & $34,23 \%$ & $34,52 \%$ & 13 \\
\hline & \begin{tabular}{|l|} 
Tyumen \\
\end{tabular} & Tyumen Oblast & 744,554 & 807,271 & $20,34 \%$ & $21,49 \%$ & 14 \\
\hline \multirow{5}{*}{ Siberian } & Novosibirsk & Novosibirsk Oblast & $1,602,915$ & $1,625,631$ & $57,67 \%$ & $58,10 \%$ & 2 \\
\hline & Omsk & Omsk Oblast & $1,178,391$ & $1,154,507$ & $59,73 \%$ & $59,92 \%$ & 14 \\
\hline & Krasnoyarsk & Krasnoyarsk Krai & $1,082,933$ & $1,093,771$ & $37,66 \%$ & $38,16 \%$ & 7 \\
\hline & Barnaul & Altay Krai & 633,301 & 632,391 & $26,77 \%$ & $27,29 \%$ & 20 \\
\hline & Irkutsk & Irkutskaya Oblast & 623,736 & 623,562 & $25,89 \%$ & $26,08 \%$ & 10 \\
\hline \multirow{4}{*}{ Far Eastern } & Khabarovsk & Khabarovsk Krai & 616,242 & 616,372 & $46,22 \%$ & $46,85 \%$ & 17 \\
\hline & Vladivostok & Primorsky Krai & 606,589 & 606.561 & $31.54 \%$ & $31,99 \%$ & 9 \\
\hline & & Russia & $146,804,400$ & $146,748,590$ & & & \\
\hline & Population & Total for 20 cities & $20,477,323$ & $20,676,799$ & & & \\
\hline & & \multicolumn{3}{|c|}{ Share of 20 cities in Russia's population } & $13,95 \%$ & $14,09 \%$ & \\
\hline
\end{tabular}

*Rostov-on-Don - cities highlighted in bold were the seat of their respective Federal District in 2017 when the ranking was made.

Source: Russian Federal State Statistics Service website (Available at http://www.gks.ru/) and author's calculations. 
Table 2 - Indicators used for the assessment of cities' international functions

\begin{tabular}{|c|c|c|c|c|}
\hline $\begin{array}{l}\text { Dimension of } \\
\text { internationali- } \\
\text { sation }\end{array}$ & & Indicator & $\begin{array}{l}\text { Input to } \\
\text { the integral } \\
\text { ranking }\end{array}$ & Source and Comment \\
\hline \multirow{3}{*}{$\begin{array}{l}\text { I. Institutional } \\
\text { Frame }\end{array}$} & $1 *$ & $\begin{array}{l}\text { Number of twinning and } \\
\text { partnership agreements with } \\
\text { foreign cities }\end{array}$ & \multirow{6}{*}{$\begin{array}{l}\text { Indicator- } \\
\text { specific ranking }\end{array}$} & $\begin{array}{l}\text { Dedicated sections of city's official websites and reports of city's } \\
\text { international offices. }\end{array}$ \\
\hline & 2* & Number of diplomatic missions & & $\begin{array}{l}\text { Official websites of regional divisions of Russian Ministry of } \\
\text { Foreign Affairs and dedicated sections of city's official websites. }\end{array}$ \\
\hline & 3* & $\begin{array}{l}\text { Number of foreign cultural } \\
\text { missions }\end{array}$ & & $\begin{array}{l}\text { Official websites of cultural missions: Alliance Française, the } \\
\text { Japan Centre, the Goethe Institute, the Jewish Agency for Israel } \\
\text { (Sokhnut), the Yunus Emre Institute, and the Confucius Institute. }\end{array}$ \\
\hline \multirow{4}{*}{$\begin{array}{l}\text { II. Infrastructural } \\
\text { Frame }\end{array}$} & $4 *$ & $\begin{array}{l}\text { Number of international-class } \\
\text { congress centres }\end{array}$ & & Internet search. \\
\hline & 5 & $\begin{array}{l}\text { Number of executive class hotels } \\
\text { (4-5 stars) }\end{array}$ & & $\begin{array}{l}\text { Compiled based on two reports of Ernst \& Young }(2016,2017) \\
\text { on international hotel brands in Russia and hotels' websites. }\end{array}$ \\
\hline & 6 & $\begin{array}{l}\text { City's Electronic } \\
\text { Internationalisation Index }\end{array}$ & & $\begin{array}{l}\text { Examination of the English-language content of city's official } \\
\text { websites and city's use of social media. }\end{array}$ \\
\hline & 7 & $\begin{array}{l}\text { Experience in hosting major } \\
\text { international events }\end{array}$ & $\begin{array}{c}\text { Additional } \\
\text { points }\end{array}$ & $\begin{array}{l}\text { Monitoring of regional and national mass media and city's official } \\
\text { websites for international events held there in } 2007-2017 \text {. }\end{array}$ \\
\hline \multirow{5}{*}{$\begin{array}{l}\text { III. Business } \\
\text { Frame }\end{array}$} & $8^{*}$ & Number of branches of MNCs & \multirow{5}{*}{$\begin{array}{l}\text { Indicator- } \\
\text { specific ranking }\end{array}$} & $\begin{array}{l}\text { Compiled based on the list of } 50 \text { largest foreign companies in } \\
\text { Russia as of } 2016 \text { (Forbes 2017) and MNCs' websites. }\end{array}$ \\
\hline & 9* & $\begin{array}{l}\text { Number of branches of } \\
\text { international banks }\end{array}$ & & $\begin{array}{l}\text { Compiled based on the list of top } 100 \text { banks by assets in Russia } \\
\text { as of } 2016 \text { (Expert.ru 2017) and international banks' websites. }\end{array}$ \\
\hline & 10 & $\begin{array}{l}\text { Number of hotels managed by } \\
\text { international operators }\end{array}$ & & $\begin{array}{l}\text { Compiled based on two reports of Ernst \& Young }(2016,2017) \\
\text { on international hotel brands in Russia. }\end{array}$ \\
\hline & 11 & Number of visa centres & & Internet search. \\
\hline & $\frac{12}{13}$ & $\begin{array}{l}\text { Value of foreign-owned property } \\
\text { Value of jointly-owned property }\end{array}$ & & "Multistat" statistical portal, data for 2013. \\
\hline
\end{tabular}

Austerics (*) marks indicators used both by V. Kolossov and M. Zotova in 2007 and by E. Mikhailova in 2017/2021.

Austerics $\left(^{*}\right)$ marks indicators used both by V. Kolossov and M. Zotova in 2007 and by E. Mikhailova in 2017.

Author: E. Mikhailova.

Table 3 - Internationalisation of Russian regional capitals: indicator-specific and final ranking

\begin{tabular}{|c|c|c|c|c|c|c|c|c|c|c|c|c|c|c|c|c|c|c|c|c|c|c|}
\hline \multirow{2}{*}{$\begin{array}{c}\text { City type } \\
\text { matching the } \\
\text { degree of } \\
\text { international } \\
\text { isation }\end{array}$} & \multirow[b]{2}{*}{ City } & \multirow[b]{2}{*}{ 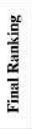 } & \multirow[b]{2}{*}{ 总 } & \multicolumn{5}{|c|}{ Institutional Frame } & \multicolumn{6}{|c|}{ Infrastructural Frame } & \multicolumn{8}{|c|}{ Business Frame } \\
\hline & & & & 势 & 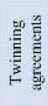 & 雲总 & 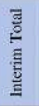 & $\begin{array}{l}\text { है } \\
\text { है } \\
\text { है } \\
\text { है }\end{array}$ & है & 受。 & 旅 & & 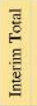 & & $\sum_{\Sigma}$ & 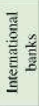 & 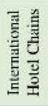 & 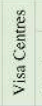 & & crty & 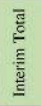 & \\
\hline $\begin{array}{l}\text { "A" type: } \\
\text { the endider of } \\
\text { mutenutionalisation }\end{array}$ & Yekaterinburg & 1 & 25 & 1 & 5 & 2 & 8 & 1 & 1 & 3 & 5 & 3 & 6 & 3 & 2 & 1 & 1 & 2 & 1 & 4 & 11 & 1 \\
\hline \multirow{5}{*}{$\begin{array}{l}\text { "B" type: } \\
\text { highly } \\
\text { internationalised }\end{array}$} & Novosibirsk & 2 & 58 & 3 & 5 & 1 & 9 & 3 & 3 & 5 & 14 & 1 & 21 & 8 & 4 & 1 & 4 & 7 & 5 & 7 & 28 & \\
\hline & Kazan & 3 & 65 & 3 & 2 & 3 & 8 & $I$ & 3 & 2 & 1 & 3 & 3 & 1 & 5 & 10 & 2 & 11 & 15 & 11 & 54 & \\
\hline & Nizhny Novgorod & 4 & 69 & 12 & 2 & 3 & 17 & 6 & 3 & 10 & 7 & 0 & 20 & 6 & 3 & 1 & 7 & 7 & 4 & 10 & 32 & 3 \\
\hline & Krasnodar & 5 & 80 & 8 & 12 & 20 & 40 & 14 & 2 & 1 & 2 & 0 & 5 & 2 & 1 & 6 & 9 & 1 & 12 & 6 & 35 & 4 \\
\hline & Rostov-on-Don & 6 & 90 & 7 & 10 & 7 & 24 & 8 & 3 & 3 & 16 & 1 & 21 & 8 & 7 & 5 & 13 & 2 & 3 & 15 & 45 & 6 \\
\hline \multirow{7}{*}{$\begin{array}{l}\text { "C" type: } \\
\text { asymmetrically } \\
\text { international ised }\end{array}$} & Samara & 7 & 106 & 8 & 5 & 7 & 20 & 7 & 20 & 15 & 15 & 0 & 50 & 19 & 9 & 1 & 2 & 11 & 8 & 5 & 36 & 5 \\
\hline & Krasnoyarsk & 7 & 106 & 8 & 2 & 20 & 30 & 10 & 3 & 7 & 2 & 1 & 11 & 4 & 13 & 6 & 7 & 6 & 19 & 14 & 65 & 12 \\
\hline & Vladivostok & 9 & 112 & 2 & 9 & 3 & 14 & 5 & 3 & 17 & 10 & 1 & 29 & 12 & 16 & 12 & 13 & 2 & 10 & 16 & 69 & 14 \\
\hline & Irkulsk & 10 & 121 & 5 & 5 & 3 & 13 & 4 & 3 & 18 & 10 & 1 & 30 & 13 & 15 & 15 & 13 & 2 & 14 & 19 & 78 & 17 \\
\hline & Ufa & 11 & 122 & 8 & 14 & 11 & 33 & 12 & 3 & 15 & 2 & 0 & 20 & 6 & 13 & 6 & 9 & 18 & 6 & 17 & 69 & 14 \\
\hline & Volgograd & 12 & 123 & 20 & 1 & 11 & 32 & 11 & 3 & 8 & 16 & 0 & 27 & 11 & 8 & 12 & 12 & 18 & 2 & 12 & 64 & 11 \\
\hline & Chelyabinsk & 13 & 131 & 20 & 19 & 20 & 59 & 19 & 3 & 5 & 8 & 1 & 15 & 5 & 16 & 6 & 9 & 6 & 17 & 3 & 57 & 9 \\
\hline \multirow{7}{*}{ 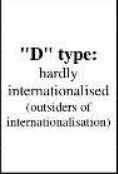 } & Omsk & 14 & 144 & 12 & 12 & 20 & 44 & 15 & 3 & 18 & 5 & 0 & 26 & 10 & 6 & 15 & 13 & 11 & 11 & 18 & 74 & 16 \\
\hline & Tyumen & 14 & 144 & 20 & 20 & 20 & 60 & 20 & 3 & 12 & 16 & 1 & 30 & 13 & 19 & 11 & 4 & 11 & 7 & 2 & 54 & 7 \\
\hline & Perm & 16 & 154 & 20 & 17 & 7 & 44 & 15 & 20 & 12 & 16 & 0 & 48 & 18 & 11 & 12 & 13 & 8 & 9 & 9 & & 10 \\
\hline & Khabarovsk & 17 & 157 & 5 & 15 & 7 & 27 & 9 & 20 & 11 & 10 & 0 & 41 & 15 & 19 & 20 & 20 & 11 & 18 & 1 & 89 & 19 \\
\hline & Saratov & 18 & 159 & 12 & 11 & 11 & 34 & 13 & 20 & 12 & 9 & 0 & 41 & 15 & 10 & 19 & 20 & 11 & 16 & 8 & 84 & 18 \\
\hline & & 19 & 167 & 20 & 15 & 20 & 55 & 17 & 20 & 9 & 16 & 0 & 45 & 17 & 11 & 15 & 4 & 11 & 13 & 13 & & \\
\hline & Barnaul & 20 & 219 & 20 & 17 & 20 & 57 & 18 & 20 & 20 & 10 & 0 & 50 & 19 & 16 & 18 & 20 & 18 & 20 & 20 & 112 & 20 \\
\hline
\end{tabular}

'Exrra points, not ranking.

Author: E. Mikhailova. 


\section{Ranking Results}

The section below discusses each dimension of city internationalisation in turn.

\section{Institutional Frame}

The allocation of diplomatic missions among Russian regional capitals is uneven (see illustration 2). Six cities in the sample do not have any diplomatic missions, another seven cities have one or two of them. Yekaterinburg with 15 diplomatic missions is leading the list while Vladivostok holds the second place with 9 diplomatic missions as of 2017. Interestingly both cities witnessed closure of diplomatic missions stationed there: the Consulate of Bulgaria in Yekaterinburg was shut down in 2011 and the General Consulate of Ukraine in Vladivostok was shut down in 2012.

Illustration 2 - Institutional internationalisation of Russian regional capitals: number of diplomatic missions, twinning agreements and cultural missions as of 2017

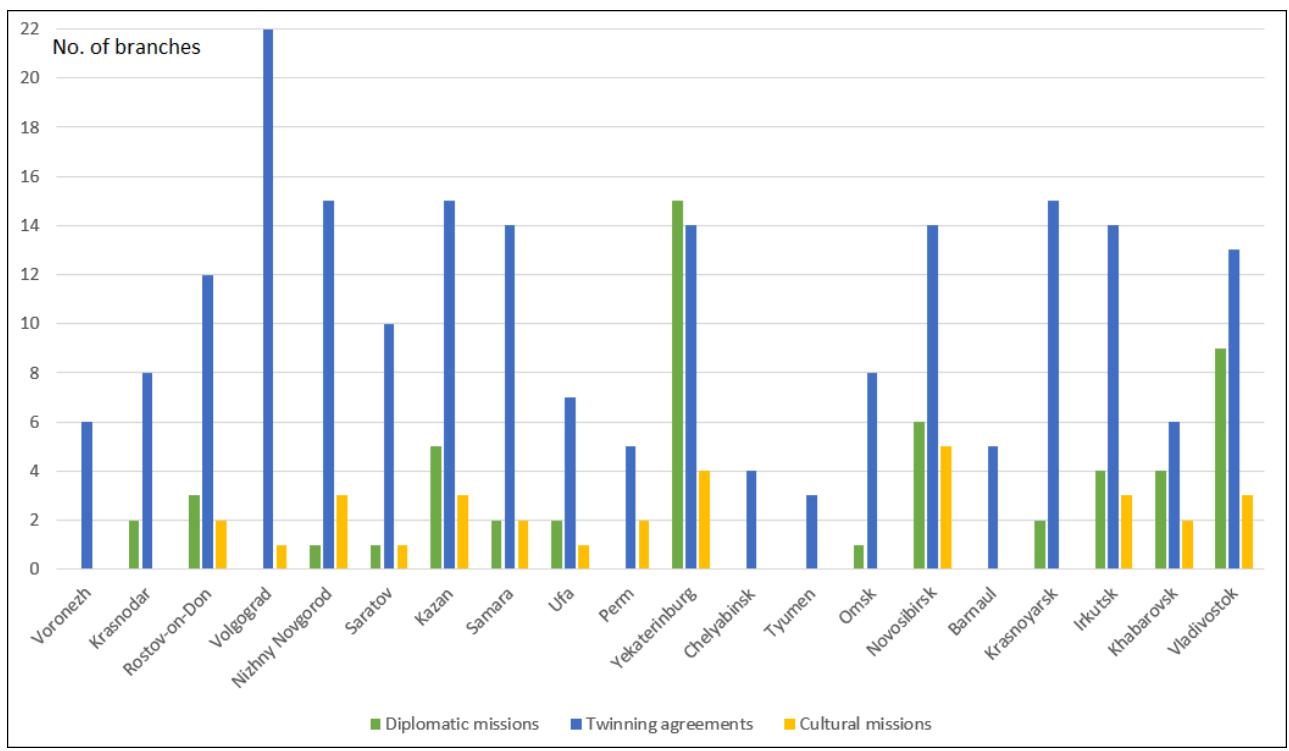

Author: E. Mikhailova.

In contrast to diplomatic missions, the development of twinning relations is more even: 10 out of 20 large Russian regional capitals have 12 or more foreign partner cities. This brings evidence to the hypothesis of Kolossov and Eckert (2007) that centres of the nation-state diplomacy and paradiplomacy often do not coincide. For example, Volgograd has the widest network of twinned cities (22) but does not have a single diplomatic mission. Nizhny Novgorod and Krasnoyarsk have 15 twinning agreements each, but only one or two diplomatic missions.

Russian regional capitals rarely serve as platforms for establishing cultural missions. Seven cities in the sample have no cultural missions while another seven cities have one or two. Novosibirsk and Yekaterinburg with 5 and 4 cultural missions respectively lead the list. Third place is shared by four cities - Irkutsk, Kazan, Nizhny Novgorod and Vladivostok - each hosting three cultural missions. Out of 32 cultural missions operating in Russian regional capitals in 2017, $65 \%$ promoted languages and cultures of Asian and Middle Eastern countries - China, Israel, Japan and Turkey. This proportion 
is rather new as cultural missions of some countries - Ukraine's trade missions, UK's British Council offices and USA's "American Corners"4 - have been closed in Russia between 2007 and 2017.

Besides, it is worth noticing that not all cities that were seats of Federal Districts in 2017 have been unconditional leaders of institutional internationalisation. In 2017 Kazan and Vladivostok have outperformed their respective Federal District capitals Nizhny Novgorod and Khabarovsk - by the number of diplomatic missions and were on a par with them in terms of the number of cultural missions. Hence, the national administrative hierarchy does not directly translate into institutional capital.

All in all, three cities stand out due to their developed organizational and legal setups of institutional internationalisation. They are Yekaterinburg, Kazan and Novosibirsk.

\section{Infrastructural Frame}

Many Russian regional capitals lack the hard and soft infrastructure necessary for international cooperation and multinational businesses. Six cities in the sample had no congress halls, seven cities had no five-star hotels. Six cities had no English version of their website and one city's English website was not operational. With such infrastructure gaps it is hardly surprising that by 2017 eleven cities in the sample had no experience in hosting major international events.

Which cities have infrastructure conducive to internationalisation? Yekaterinburg and Krasnodar are leading in terms of exhibition halls and congress facilities with 3 and 2 congress centres respectively. The leaders by the number of executive hotels are Krasnodar (29), Kazan (22), Yekaterinburg and Rostov-on-Don (21 executive hotels each). The majority of executive hotels in Russian regional capitals are four-star hotels. If we focus on five-star hotels Kazan and Yekaterinburg would lead the list with 4 fivestar hotels each.

Yekaterinburg and Kazan were the most experienced cities in terms of hosting major international events: by 2017 both cities had hosted three such events. Yekaterinburg has hosted the Shanghai Cooperation Organization Summit and the BRIC summit in 2009 as well as the Russia-EU Summit in 2013, all three events were attended by heads of government of participating countries. Kazan hosted the 27th World Summer Universiade in 2013, the World Aquatics Championship in 2015 and the FIFA Confederations Cup in 2017. Only the first of these events was attended by heads of government. The nature of international events hosted by Yekaterinburg and Kazan differs significantly. While Kazan hosted international sport events that required facilities for holding top-level competitions, accommodating and catering to foreign athletes, tourists and journalists, Yekaterinburg hosted multilateral political events pertaining to the realm of international relations attended by top-politicians, diplomats, business community and journalists.

The indisputable champion in electronic internationalisation in 2017 was Kazan. This is not surprising: as pointed out in several studies (Bagautdinova et al., 2015; Makarychev et Yatsyk, 2015), Kazan has been among early adopters of new information and communication technologies in Russia, and has a long record of effective PR. By 2017 Kazan had social media accounts in Facebook, Twitter and Vkontakte, a mayor's website and a dedicated website for investors. The city's official website was the most 
updated and provided the most comprehensive information about Kazan and its investment projects.

Krasnoyarsk, Krasnodar and Ufa share the second place in the electronic internationalisation ranking. English versions of their websites provided a broad range of information but some sections had not been updated for several years.

After considering all the components of infrastructural internationalisation, Kazan, Krasnodar and Yekaterinburg stand out as the three leaders.

\section{Business Frame}

Multinational corporations (MNCs), international banks and visa centres are present in all cities in the sample. The largest number of MNC branches of 50 largest foreign companies operating in Russia as of 2016 functioned in Krasnodar (50), Yekaterinburg (48), Nizhny Novgorod (46) and Novosibirsk (42) (see illustration 3). The largest number of international banks included in the top 100 banks by assets operating in Russia as of 2016 - 17 branches - operated in Yekaterinburg, Nizhny Novgorod, Novosibirsk and Samara.

Illustration 3 - Business internationalisation of Russian regional capitals: number of MNCs, international banks, hotel chains managed by international operators and visa centres as of 2017

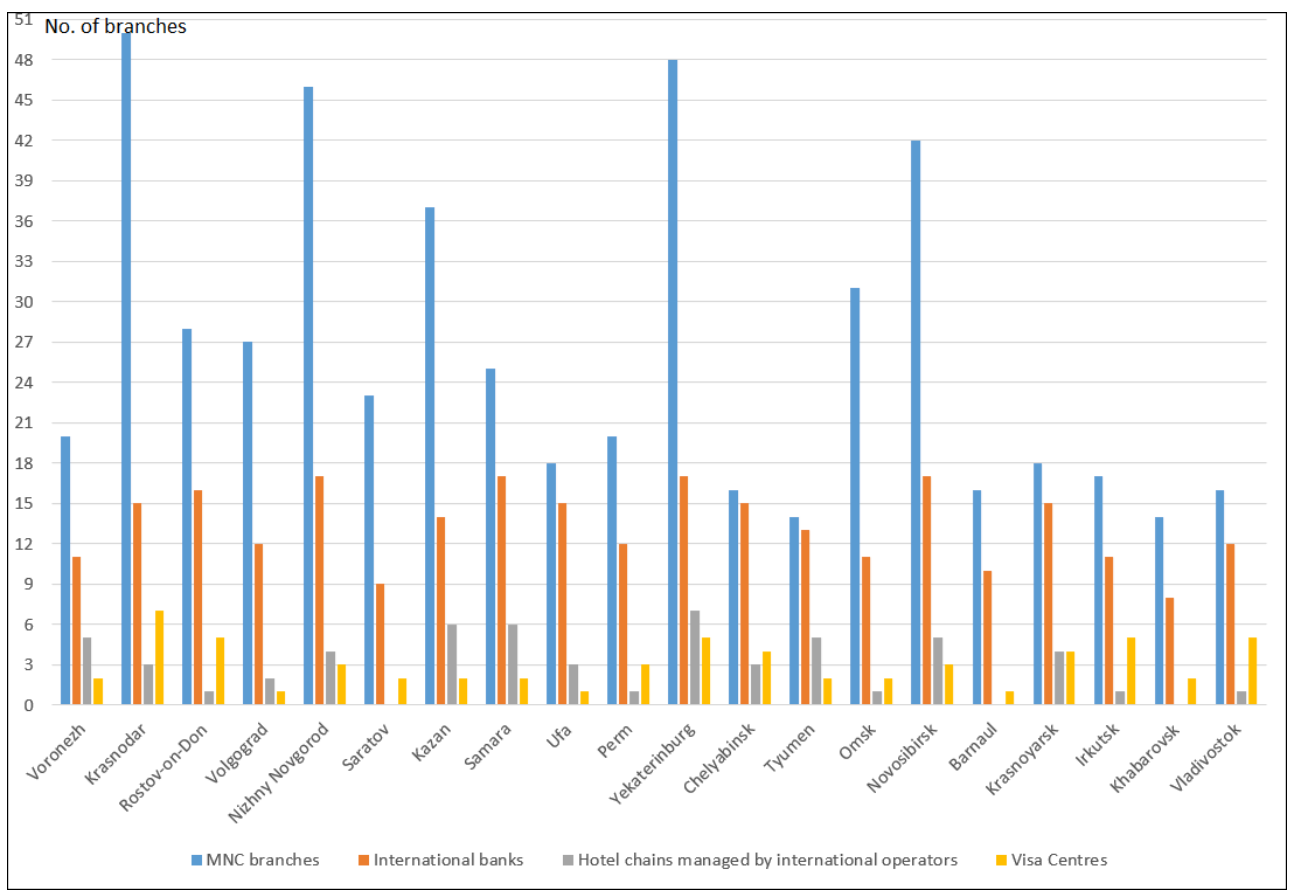

Author: E. Mikhailova.

The largest number of hotel chains managed by international operators was running in Yekaterinburg (7), Kazan and Samara (6 each), Novosibirsk, Tyumen and Voronezh (5 each). Three cities in the sample had no such hotels: Barnaul, Khabarovsk and Saratov.

The leader in terms of visa centres was Krasnodar (7). Second place was shared by Yekaterinburg, Rostov-on-Don, Irkutsk and Vladivostok - each having 5 visa centres. In five cities - Yekaterinburg, Volgograd, Rostov-on-Don, Nizhny Novgorod and Novosibirsk - the value of foreign-owned property was between $8 \mathrm{mln}$ and $14 \mathrm{mln}$ 
rubles in 2013 (see illustration 4). Yekaterinburg with $13.9 \mathrm{mln}$ rubles value of foreignowned property got the first rank.

The three red spikes on illustration 4 - the chart of jointly-owned property - stand for Khabarovsk, Tyumen and Chelyabinsk. There the value of jointly-owned property ranged between $13 \mathrm{mln}$ and $25 \mathrm{mln}$ rubles in 2013. Khabarovsk with $24.5 \mathrm{mln}$ rubles value of jointly-owned property got the first rank.

Illustration 4 - Business internationalisation of Russian regional capitals: value of foreign-owned and joint-owned property by 2013

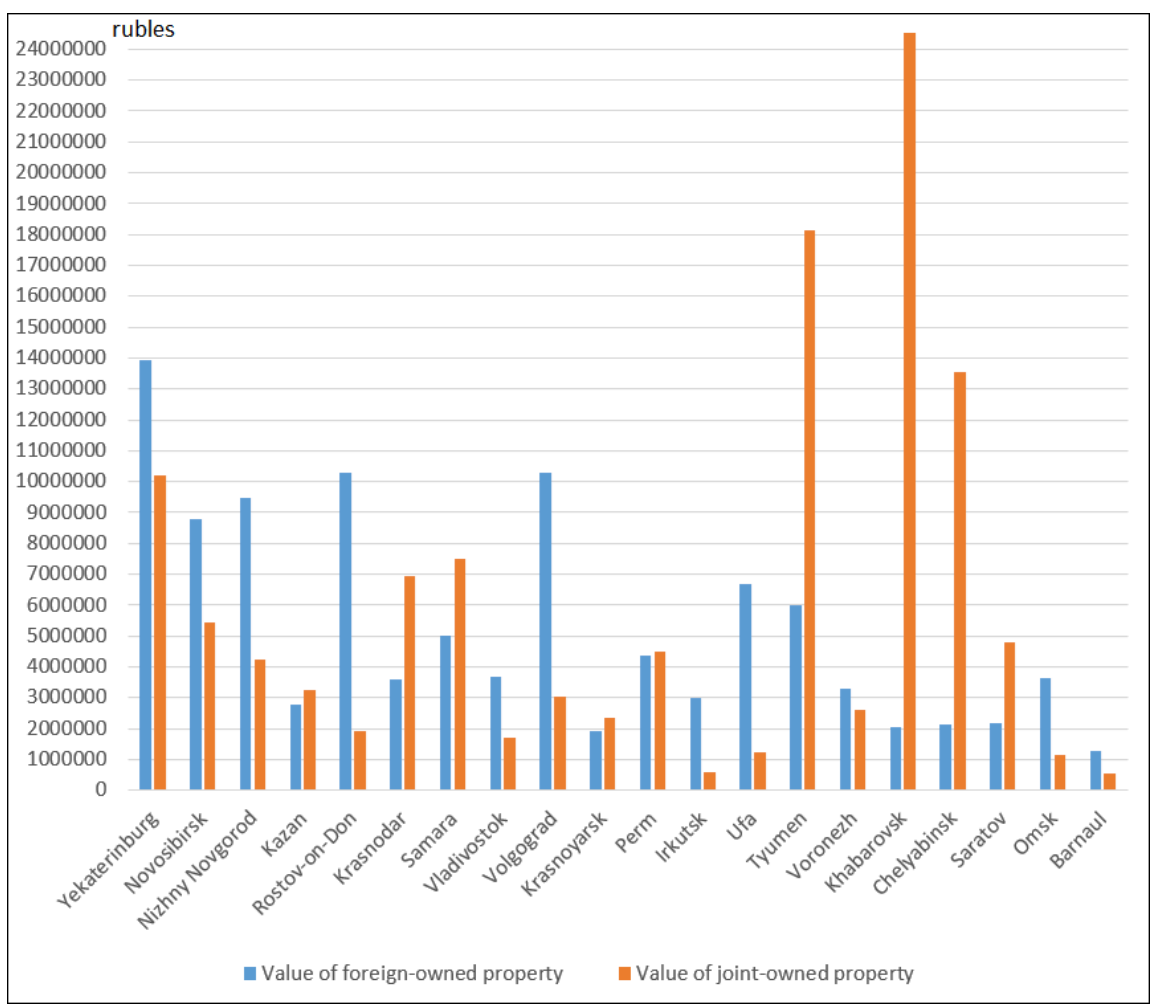

Author: E. Mikhailova.

\section{Integral ranking}

Based on the integral, interim and indicator-specific rankings, the cities in the sample have been grouped into four types (see table 3 and illustration 5). The "A" type represents the leader of internationalisation - Yekaterinburg - with equally strong institutional, infrastructural and business internationalisation.

The "B" type corresponds to five highly internationalised Russian cities each demonstrating at least two strong dimensions of internationalisation. All of them have been ranked as top three for at least four indicator-specific rankings and have not been ranked among the last five in indicator-specific rankings more than once.

The " $C$ " type unites asymmetrically internationalised cities with one dimension of internationalisation being highly internationalised, another somewhat internationalised and the other hardly internationalised. On the one hand, they have been ranked in the top three in indicator-specific rankings between two and four times. On the other hand, they have been ranked among the last five in indicator-specific rankings twice or more with low ranks typically concentrating in one 
internationalisation frame.

Finally, the "D" type includes hardly internationalised cities that are outsiders of internationalisation - those with a total score over 132 points. All of them have received the five lowest ranks three times or more including the lowest 20th rank at least once.

In support of Neal's (2011) hypothesis that the correlation between a city's size and its position in the contemporary urban network is decreasing, the internationalisation ranks of several large Russian cities are significantly lower than their ranks in terms of their population size. For instance, Chelyabinsk and Omsk have been 5th and 6th among the cities in the sample by population size in 2017 but only 13th and 14th by internationalisation respectively. This rank disparity can be explained by the dominance of the manufacturing sector in urban economies and the relatively slow development of the tertiary sector.

Illustration 5 - The four-fold typology of Russian regional capitals based on their total scores in the internationalisation ranking

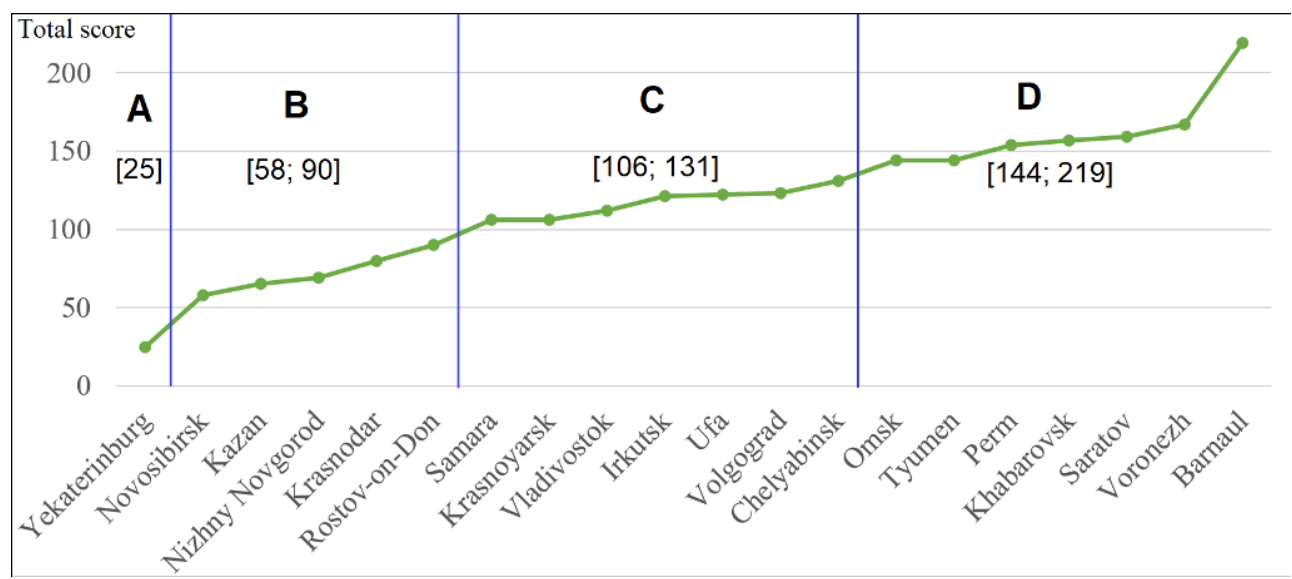

Author: E. Mikhailova.

Yekaterinburg is a confident leader of internationalisation among Russian regional capitals with an almost twofold margin over the nearest competitor. It scored first in two out of three interim total rankings and in the integral ranking. The high number of diplomatic and cultural missions, MNCs, international and executive hotels attests to the city's political and economic centrality.

Novosibirsk comes second but it significantly lags behind Yekaterinburg - with 58 points vs. 25 points. Its interim rankings vary from being the 2nd to being the 8th such a broad range testifies to a less coherent degree of internationalisation in different spheres of life. Kazan holds the third place with 65 points, closely followed by Nizhny Novgorod with 69 points. Interestingly, the four cities represent three Federal Districts - the Ural, the Siberian and the Volga Federal Districts - suggesting that leaders of internationalisation accumulate central functions for their respective Federal Districts. Kazan and Nizhny Novgorod both come from the Volga Federal District what makes them compete over the central functions within the District.

Although Novosibirsk was ranked first in a number of indicators (such as the number of cultural missions and international banks stationed there), it was noticeably behind Yekaterinburg in terms of its electronic internationalisation ranking and the value of 
joint-owned property. It also has fewer executive and international hotels and visa centres.

57 Kazan demonstrated strong institutional and infrastructural internationalisation but more modest business internationalisation. It has a developed network of hotels - both executive - class and those managed by international operators, it hosted three major international events by 2017 and was exemplary in terms of city's international online marketing activities.

Nizhny Novgorod on the contrary was more successful in business internationalisation as is exhibited by its high numbers of MNC branches and international banks and high value of foreign-owned property. At the same time Nizhny Novgorod has a less developed hotel network, fewer diplomatic missions, more basic electronic internationalisation and had not hosted any major international events as of 2017. Krasnodar was ranked the fifth (with the total score of 80 points) and had overperformed Rostov-on-Don that was ranked the sixth (90 points), despite the latter being the seat of the Southern Federal District and having a larger population. Over the past 20 years Krasnodar, as a regional capital with strong agricultural, industrial, logistics and recreational functions, has succeeded in its infrastructural and business internationalisation. It has developed a modern network of executive and international hotels, congress halls and visa centres and has persuaded many MNCs to open their branches there. Krasnodar also has succeeded in its electronic internationalisation by preparing and maintaining exceptionally informative city-run Internet resources in English as of 2017.

Rostov-on-Don too has a strong business internationalisation as evidenced by the large number of MNC branches, visa centres, congress halls and the high value of foreignowned property. At the same time, by 2017, the city had invested little in its international online marketing - it did not have an English version of its website.

\section{Discussion}

61 The results of the 2017 ranking confirm some of the trends reported in other studies dedicated to studying the integration of the Russian urban system into the world economy.

Yekaterinburg has been called Russia's "third capital" for over a decade (Zotova, 2007). The city has created a favourable image at the national level and is gradually strengthening its macro-regional influence. This is confirmed by the number of important international and national events held in the city. As pointed by Müller and Trubina (2020, p. 670-671), Yekaterinburg has been "exercising the art of becoming global" and experimenting in "turning its economic capital into cultural capital" to establish itself as an urban hub between the East and the West. As the ranking shows, this experimenting has been rather successful.

Pondering the leading position of Novosibirsk, Usmanova et al. (2021) refer to the city's new role acquired in post-Soviet times: that of an intermediary between China and the rest of Siberia, notably in the import of Chinese goods. Besides, the researchers point at the remarkable scientific and educational complex of Novosibirsk known as Akademgorodok (Academy town) as another strategic competitive advantage over other large Russian cities. Akademgorodok is the third largest scientific center in 
Russia that accumulates "almost half of higher educational institutions of Siberia and the Russian Far East" (Usmanova et al., 2021, p. 6).

The leading role of Yekaterinburg and Novosibirsk as cities with the highest centrality was highlighted in 2007 by Kolossov and Eckert (2007, p. 123). Already then, the former was leading as a centre of railway communications and the latter as a centre of airways communications.

The top-four cities of the present ranking coincide with the top-four ${ }^{5}$ of the ranking produced by Rogov and Rozenblat (2020). At the same time, the order of cities in these two rankings is slightly different: according to Rogov and Rozenblat (2020, p. 28), the highest number of multinational firms in 2019 was in Kazan followed by Novosibirsk, Yekaterinburg and Nizhny Novgorod (if measured strictly within city's political boundaries). If measured by large urban regions (LURs), the composition of the topfour cities changes: while Kazan and Yekaterinburg retain their 1st and 2nd ranks, Nizhny Novgorod becomes the 3rd and Rostov-on-Don becomes the 4th.

The present ranking confronts the findings of Ershova and Orlovskaya (2018) where neither Yekaterinburg nor Novosibirsk are seen as leaders of internationalisation. In fact, they are assigned to the group of cities "lagging far behind" Moscow and St. Petersburg in terms of their degree of globalisation. They are included in the same group as Omsk and Voronezh (ranked 14th and 19th respectively in the present study). The leading lights in internationalisation according to Ershova and Orlovskaya (2018) are Krasnoyarsk and Kazan (ranked 7th and 3th respectively in the present study) due to their high scores of HDI and the index of urban environment quality. The reason for such a discrepancy lies in the narrow understanding of internationalisation used by Ershova and Orlovskaya who did not include any political or economic indicators for their ranking.

67 A recent comparative study of Krasnoyarsk and Novosibirsk by Usmanova, Ligaeva and Kuznetsova (2021) also challenges the study of Ershova and Orlovskaya (2018). Usmanova, Ligaeva and Kuznetsova conclude that, despite the brisk post-Soviet development of Krasnoyarsk and its region due to raw materials export and development of manufacturing industries, the leadership of Novosibirsk in Siberia has not been undermined.

Among Russian regional capitals in the sample, Kazan perhaps is the one that has been enjoying particularly significant attention both in international mass media and in English-language academic publications. Presumably, it is due to the intrinsic characteristics of the city (i.e. multi-ethnicity and multi-confessionality), the events it has hosted (among others the 27th World Summer Universiade and the 2018 FIFA World Cup) and the city's policies. As aptly pointed by Makarychev and Yatsyk, in order to positively differentiate itself "from many other post-Soviet transitional, dissonant and ethnically conflictual places", over time Kazan has shifted from projecting itself as Russia's "Islamic capital" or, more globally, the interface between the Muslim and Orthodox worlds, to presenting itself as Russia's sports capital (2015, p. 153). As the present ranking and the ranking by Rogov and Rozenblat (2020) have shown, this strategic choice bore fruit - Kazan is in the top-three of globalised large Russian cities. This is also confirmed by Makarychev and Yatsyk who compared the branding strategies of Nizhny Novgorod and Kazan and concluded that, while the image of the former is blurred and poorly articulated, the latter with its "ethnically coloured brand" 
(2021, p. 155) has already become internationally visible and has a high potential for enhancing its recognition globally.

\section{Conclusion}

Thirty years ago, following the dissolution of the USSR, Russia's major regional capitals embarked on internationalisation. As has been confirmed and elaborated by this study, over that time, they have reached different levels of involvement in the global economy and the world-city network.

To better grasp the unequal internationalisation of large Russian cities, a four-fold typology of large Russian cities on the basis of their degree of internationalisation has been proposed. Yekaterinburg has achieved the highest degree of internationalisation in 2017 and corresponds to the "A" type. Following Moscow and St. Petersburg, it was the first to engage in international cooperation, for which it had the best prerequisites - above all, human capital. Yekaterinburg has the support of municipal, regional and national authorities to internationalise, and aspire to become a crucial part of the global urban system. The leader is followed by Novosibirsk, Kazan, Nizhny Novgorod, Krasnodar and Rostov-on-Don (the "B" type), which are far ahead of the other cities in the sample. The two other types include seven cities each - those with the asymmetric internationalisation (the " $\mathrm{C}$ " type) and the outsiders of internationalisation (the "D" type). The involvement of these cities in the globalisation processes is still rather limited. They mainly perform central functions within the boundaries of their regions or Federal Districts. Such unequal internationalisation of large Russian cities is due to the country's size, high degree of political centralisation and recently to the increased tensions in Russia's relations with the West.

While it is often hard to see clearly the implication of the city's rank in "real" life, one could speculate that the degree of internationalisation is imprinted both in the urban landscape (via presence of infrastructure, MNCs, international events and foreign tourists) and the standard of living in a particular city (via broader job and leisure opportunities, better access to traveling abroad or sampling foreign culture at home thanks to events arranged by the diplomatic and cultural missions). Besides, a higher internationalisation rank embodies a well-rounded city's development that combines extensive and solid official external ties, developed infrastructure, diversified economy and competitive businesses.

The paper has showcased that the leadership in institutional internationalisation of some cities acting as a seat of Federal Districts in 2017 has been contested by other cities in the same Federal District. It was then concluded that the high position in the national administrative hierarchy does not directly lead to a higher degree of internationalisation and more advanced institutional capital.

The paper has confirmed hypotheses of several previous studies. First, the decreasing correlation between a city's size and its position in the contemporary urban network (Neal 2011) was demonstrated by the discrepancy between the internationalisation ranks of several large Russian cities and their ranks in terms of population size. Second, a survey of diplomatic missions and twinning agreements of large Russian cities confirms the divergence between the centres of nation-state diplomacy and paradiplomacy noted earlier by Kolossov and Eckert (2007). 

internationalisation remains an important resource for development of large Russian cities. As argued in several studies (Joenniemi, 2014, p. 3-4; Tavares, 2016, p. 46-47), when interstate political dialogue is constrained, other channels of bilateral and multilateral communications including international activities at the city-level have a more important role to play. This is already happening and could be illustrated with the appointment of Ilsur Metshin, the Mayor of Kazan, as a chair of the United Nations Advisory Committee of Local Authorities (UNACLA), a high-level committee of selected mayors and city network representatives that serves as an advisory body to the UN System, in 2020 (The Global Taskforce of Local and Regional Governments, 2020). community and to practitioners. On the one hand, the study has contributed to the literature discussing the mode of Russian internationalisation. On the other, it sheds light on still globalising cities, puts them in a comparative perspective and reveals cities that have remained less connected with the rest of the globalising world - the asymmetrically internationalised and hardly internationalised cities. To stimulate the global connectivity of these cities, national, regional and local governments need to take additional measures by launching policies and projects addressing the weak dimensions of internationalisation. More specifically, targeted funding for publicprivate partnerships dedicated to the infrastructural development of Russian regional capitals, guidance on international online marketing and communication with potential investors could allow increasing the appeal of large Russian cities to the global economic actors.

Besides the ranking findings, the paper puts forward the electronic internationalisation index - a tool for qualitative benchmarking of city's international online marketing activities and assessing its comprehensiveness. This tool might be of interest both for the future academic and applied research.

\section{BIBLIOGRAPHY}

Acuto M., Leffel B., 2020. Understanding the global ecosystem of city networks. Urban Studies, p. 1-17.

Akande A., Cabral P., Gomes P., Casteleyn S., 2019. The Lisbon ranking for smart sustainable cities in Europe. Sustainable Cities and Society, $\mathrm{n}^{\circ} 44,475-487$.

Bagautdinova N. G., Mingazova N. M., Zamaletdinov R. I., et al., 2015. Economic, social and environmental aspects of the impact of the universiade-2013 on development of Kazan city and Tatarstan Republic. Asian Social Science, vol. 11, n 11, p. 115.

Bell J., McNaughton R., Young S., Crick D., 2003. Towards an integrative model of small firm internationalisation. Journal of international entrepreneurship, vol. 1, $\mathrm{n}^{\circ}$ 4, p. 339-362.

Blank Y., 2010. Federalism, subsidiarity, and the role of local governments in an age of global multilevel governance. Fordham Urb. LJ, nº 37, p. 509-558.

EchoGéo, 56 | 2021 
Brenner N., 1999. Globalisation as reterritorialisation: the re-scaling of urban governance in the European Union. Urban studies, vol. 36, n 3, p. 431-451.

Brenner N., 2009. Cities and Territorial Competitiveness. The SAGE handbook of European studies, p. $442-463$.

Castells M., 1996. The information age: economy, society and culture. Vol. 1. The rise of the network society. Blackwell, Cambridge, MA.

Castells M., 2002. Local and global: Cities in the network society. Tijdschrift voor economische en sociale geografie, vol. $93, \mathrm{n}^{\circ}$ 5, p. 548-558.

Corijn E., Vandermotten C., Decroly J. M., Swyngedouw E., 2009. Brussels as an international city. Brussels Studies, $\mathrm{n}^{\circ} 13$.

Derudder B., Cao Z., Liu X., et al., 2018. Changing connectivities of Chinese cities in the world city network, 2010-2016. Chinese Geographical Science, vol. 28, n 2, p. 183-201.

Duchacek I. D., 1987. Toward a typology of new subnational governmental actors in international relations.

Dumont G. F., 2018. Urban Demographic Transition (La transition démographique urbaine). Urban development issues, $\mathrm{n}^{\circ} 56$.

Ernst \& Young, 2016. Hotels managed by international operators in Russia. Available at: https:// ru.investinrussia.com/data/files/sectors/EY-international-hotel-brands-review-2016.pdf (accessed 05.02.2021) [In Russ.]

Ernst \&Young, 2017. International hotel brands in Russia 2017. Ernst \& Young Report [In Russ.]

Ershova S., Orlovskaya T., 2018. Comparative researches on strategic priorities of Russian megalopolises and global cities. In IOP Conference Series: Materials Science and Engineering, vol. 463, $\mathrm{n}^{\circ}$ 3. IOP Publishing. DOI: https://doi.org/10.1088/1757-899X/463/3/032037

Expert.ru, 2017. 100 largest banks in Russia by assets as of July 1, 2016. Available at: https://expert.ru/ ratings/100-krupnejshih-bankov-rossii-po-razmeru-aktivov-na-1-iyulya-2016-godax/ (accessed 11.02.2021) [In Russ.]

Forbes, 2017. 50 largest foreign companies in Russia. Available at: https://www.forbes.ru/rating/ 350867-50-krupneyshih-inostrannyh-kompaniy-v-rossii-2017 (accessed 11.02.2021) [In Russ.]

Friedmann J., 1986. The world city hypothesis. Development and Change, n 17, p. 69-84.

GaWC, 2018. The World According to GaWC 2018. Available at: https://www.lboro.ac.uk/gawc/ world2018.html (accessed 11.02.2021)

GaWC, 2020. The World According to GaWC 2020. Available at: https://www.lboro.ac.uk/gawc/ world2020.html (accessed 11.02.2021)

Halbert L., Cicile P., Pumain D., Rozenblat C., 2012. Quelles métropoles en Europe ? Analyse comparée. Synthèse. Available at: https://docplayer.fr/3641190-Quelles-metropoles-en-europe-analysecomparee-synthese-ludovic-halbert-patricia-cicille-denise-pumain-celine-rozenblattravaux.html (accessed 22.05.2021)

Herod A., 2003. Scale: the local and the global. Key concepts in geography, n 229, p. 234.

Jayne M., Hubbard P., Bell D., 2011. Worlding a city: Twinning and urban theory. City, $\mathrm{n}^{\circ} 1$, p. 25-41. 
Joenniemi P., 2014. City-twinning as Local Foreign Policy: The Case of Kirkenes-Nickel. CEURUS EU-Russia Paper. Available at: http://ceurus.ut.ee/wp-content/uploads/2011/06/EU-Russianpaper-15_Joenniemi.pdf (accessed 22.05.2021)

Keating M., 1999. Regions and international affairs: Motives, opportunities and strategies. Regional \& Federal Studies, vol. 9, n 1, p. 1-16.

Knight J., 2004. Internationalization remodeled: Definition, approaches, and rationales. Journal of studies in international education, vol. 8, $\mathrm{n}^{\circ} 1, \mathrm{p} .5-31$.

Knox P. L., Taylor P J.(eds.), 1995. World cities in a world-system.

Kolossov V., Eckert D., 2007. Russian regional capitals as new international actors: the case of Yekaterinburg and Rostov. Belgeo. Revue belge de géographie, nº 1, p. 115-132.

Kolossov V., Vendina O., O'Loughlin J., 2002. Moscow as an emergent world city: international links, business developments, and the entrepreneurial city. Eurasian Geography and Economics, vol. 43, n³, p. 170-196.

Makarychev A., Yatsyk A., 2015. Brands, cities and (post-) politics: A comparative analysis of urban strategies for the Universiade 2013 and the World Football Cup 2018 in Russia. European Urban and Regional Studies, vol. 22, $\mathrm{n}^{\circ} 2, \mathrm{p} .143-160$.

Marcuse P., van Kempen R., 2000. Globalising cities: a new spatial order? Blackwell, Oxford.

McCann E. J., 2004. Urban political economy beyond the 'global city'. Urban Studies, vol. 41, $\mathrm{n}^{\circ} 12$, p. 2315-2333.

Mikhailova E., Zotova M., Kolossov V., 2021. International functions of large Russian cities, In GeoUrban Studies and Urban Planning: Theoretical and Applied Research. Moscow, Moscow, Lomonosov Moscow State University, p. 187-201 [In Russ.]

Müller M., Trubina E., 2020. Improvising urban spaces, inhabiting the in-between. Environment and Planning D: Society and Space, vol. 38, $\mathrm{n}^{\circ}$ 4, p. 664-681.

Neal Z., 2011. From central places to network bases: A transition in the U.S. urban hierarchy, 1900-2000. City and Community, $n^{\circ} 10$, p. 49-75.

Robinson, J., 2002. Global and world cities: a view from off the map. International journal of urban and regional research, vol. $26, \mathrm{n}^{\circ} 3$, p. 531-554.

Rogov M., Rozenblat C., 2020. Delineating Russian cities in the perspective of corporate globalisation : towards Large Urban Regions. Cybergeo: European Journal of Geography.

Rozenblat C., 2018. Urban Systems Between National and Global: Recent Reconfiguration Through Transnational Networks. In International and Transnational Perspectives on Urban Systems. Springer, Singapore, p. 19-49.

Rozenblat C., Pumain D., 2018. Metropolization and polycentrism in the European Urban system. In International and transnational perspectives on urban systems. Springer, Singapore, p. 117-141.

Sassen S., 1991. The Global City: New York, London, Tokyo. Princeton, Princeton University Press.

Shin K. H., Timberlake M., 2000. World cities in Asia: cliques, centrality and connectedness. Urban studies, vol. $37, \mathrm{n}^{\circ} 12$, p. 2257-2285.

Sigler T. J., 2016. After the 'world city' has globalised: Four agendas towards a more nuanced framework for global urban research. Geography Compass, vol. 10, n 9, p. 389-398. 
Soldatos P., 1991. Strategic cities alliances: An added value to the innovative making of an international city. Ekistics, p. 346-350.

Tavares R., 2016. Paradiplomacy: cities and states as global players. Oxford University Press.

Taylor P. J., Derudder B., 2004. Porous Europe: European cities in global urban arenas. Tijdschrift voor economische en sociale geografie, vol. 95, n 5, p. 527-538.

Taylor P.J., Derudder B., Saey P., Witlox F., 2007. Introduction: cities in globalisation. In Taylor P., Derudder B., Saey P., Witlox F. (eds.), Cities in globalisation: Practices, policies and theories. Routledge, p. 13-18.

The Global Taskforce of Local and Regional Governments, 2020. Mayor Metshin of Kazan appointed chair of UNACLA at the World Urban Forum 2020. Available at: https://www.global-taskforce.org/ mayor-metshin-kazan-appointed-chair-unacla-world-urban-forum-2020 (accessed 26.05.2021)

Timberlake M., Wei, Y. D., Ma, X., \& Hao, J., 2014. Global cities with Chinese characteristics. Cities, $\mathrm{n}^{\circ} 41$, p. 162-170.

Timofeev I. N., Makhmutov T. A., Teslya A. L., Chimiris E. S., Kuznetsova A. Y., 2016. Web Internationalisation: Russian Universities. Report $n^{\circ}$ 24/2016. Russian International Affairs Council (RIAC). Moscow, Spetskniga.

UN Statistical Commission, 2020. A recommendation on the method to delineate cities, urban and rural areas for international statistical comparisons. Available at: https://unstats.un.org/unsd/statcom/ 51st-session/documents/BG-Item3j-Recommendation-E.pdf (accessed 29.05.2021)

Usmanova I., Ligaeva N., Kuznetsova O., 2021. Sustainable spatial development: a story of Novosibirsk and Krasnoyarsk agglomerations. In E3S Web of Conferences, vol. 250. EDP Sciences. DOI: https://doi.org/10.1051/e3sconf/202125005002

Van der Knaap B., Wall R., 2005. NETSCAPE-Europe and the Evolving World City Network. ERSA conference papers, European Regional Science Association. Available at: https://ideas.repec.org/ p/wiw/wiwrsa/ersa05p491.html (accessed 11.02.2021)

Van der Pluijm R., Melissen J., 2007. City diplomacy: the expanding role of cities in international politics. Netherlands Institute of International Relations "Clingendael”.

Wang D. D., 2019. Performance assessment of major global cities by DEA and Malmquist index analysis. Computers, Environment and Urban Systems, n 77, p. 101365.

Zelinsky W., 1991. The twinning of the world: sister cities in geographic and historical perspective. Annals of the Association of American Geographers, vol. 81, $n^{\circ} 1$, p. 1-31.

Zotova M.V., 2007) Transformation of Russian Cities into Centres of Macro-Regional Influence. PhD. Moscow [In Russ.]

Zubarevich N. V., 2002. The largest cities of Russia as "agents" of globalisation. Russia and the Modern World, $\mathrm{n}^{\circ}$ 4, p. 97-101. [In Russ.]

\section{Data sources}

Multistat: multifunctional statistical portal by GMTs Rosstat. Available at: http:// www.multistat.ru/ (accessed 20.05.2021) [In Russ.]

Interactive map of territorial divisions of Russia's Ministry of Foreign Affairs (with the links to their websites). Available at: https://www.mid.ru/en/maps/ru (accessed 20.05.2021)

City's official websites 
Barnaul official website. Available at: https://barnaul.org (accessed 11.02.2021)

Chelyabinsk official website. Available at: https://cheladmin.ru (accessed 11.02.2021)

Irkutsk official website. Available at: https://admirk.ru/pages/root.aspx (accessed 11.02.2021)

Kazan official website. Available at: https://kzn.ru (accessed 11.02.2021)

Khabarovsk official website. Available at: https://www.khabarovskadm.ru (accessed 11.02.2021)

Krasnodar official website. Available at: https://krd.ru (accessed 11.02.2021)

Krasnoyarsk official website. Available at: http://www.admkrsk.ru/Pages/default.aspx (accessed 11.02.2021)

Nizhny Novgorod official website. Available at: https://admgor.nnov.ru (accessed 11.02.2021)

Novosibirsk official website. Available at: https://novo-sibirsk.ru (accessed 11.02.2021)

Omsk official website. Available at: https://admomsk.ru/web/guest/main (accessed 11.02.2021)

Perm official website. Available at: https://www.gorodperm.ru (accessed 11.02.2021)

Rostov-on-Don official website. Available at: https://rostov-gorod.ru (accessed 11.02.2021)

Samara official website. Available at: https://samadm.ru (accessed 11.02.2021)

Saratov official website. Available at: http://www.saratovmer.ru (accessed 11.02.2021)

Tyumen official website. Available at: http://www.tyumen-city.ru (accessed 11.02.2021)

Ufa official website. Available at: https://ufacity.info (accessed 11.02.2021)

Vladivostok official website. Available at: http://www.vlc.ru (accessed 11.02.2021)

Volgograd official website. Available at: http://www.volgadmin.ru/d/Home/Index (accessed 11.02.2021)

Voronezh official website. Available at: https://voronezh-city.ru (accessed 11.02.2021)

Yekaterinburg official website. Available at: https://ЕКАТЕРИНБУРГ.РФ (accessed 11.02.2021)

\section{NOTES}

1. Unfortunately, the 2007 study of Kolosov and Zotova remained unpublished but some of its results were presented in Kolossov and Eckert (2007) and Zotova (2007) and in a conference presentation that was made available to the author of this paper.

2. The comparison of the 2007 and 2017 studies is available in Russian in Mikhailova et al. (2021).

3. Federal Districts of Russia are groupings of its administrative units established in 2000 by a presidential decree to coordinate communication between Russia's President and the regional governors. By 2021, Russia has eight Federal Districts, each with its own presidential envoy.

4. "American corners" are US cultural missions that serve as regional resource centers for information and programs highlighting American culture, history, current events, and government.

5. The study of Rogov and Rozenbalt (2020) included Moscow and St. Petersburg that were indisputably leading the ranking. The comparison here is made with the rest of the cities in the ranking. 


\section{ABSTRACTS}

To assess the degree of city's internationalisation in Russia, the paper presents ranking conducted in 2017 of 20 large Russian regional capitals with over 600,000 inhabitants on the basis of 13 indicators. The paper concludes that, by 2017, Yekaterinburg has become a confident leader of internationalisation while Novosibirsk, Kazan, Nizhny Novgorod, Krasnodar and Rostov-onDon stand out as other highly internationalised large Russian cities. At the same time, 14 out of 20 Russian regional capitals in the sample demonstrate asymmetrical or weak internationalisation. Besides, the paper puts forward the electronic internationalisation index as a tool for qualitative benchmarking city's international online marketing activities.

Pour évaluer le degré d'internationalisation des villes en Russie, l'article présente le classement effectué en 2017 de 20 grandes capitales régionales russes de plus de 600000 habitants sur la base de 13 indicateurs. Le document conclut qu'en 2017, Ekaterinbourg est devenu un leader confiant de l'internationalisation, tandis que Novossibirsk, Kazan, Nijni Novgorod, Krasnodar et Rostovsur-le-Don se distinguent comme d'autres grandes villes russes hautement internationalisées. Dans le même temps, 14 des 20 capitales régionales russes de l'échantillon présentent une internationalisation asymétrique ou faible. En outre, l'article présente l'indice d'internationalisation électronique comme un outil de comparaison qualitative des activités de marketing international en ligne des villes.

\section{INDEX}

Mots-clés: grande ville russe, capitale régionale russe, internationalisation, lien extérieur, paradiplomatie, indice d'internationalisation électronique, classement des villes

Keywords: large Russian city, Russian regional capital, internationalisation, external ties, paradiplomacy, electronic internationalisation index, city ranking

\section{AUTHOR}

\section{EKATERINA MIKHAILOVA}

Ekaterina Mikhailova, ekaterina.mikhailova@etu.unige.ch, is a Postdoctoral Researcher and an awardee of the Swiss Government Excellence Scholarship for 2020-2021, University of Geneva. She recently published:

- Garrard J., Mikhailova E., 2019. Twin Cities: Urban Communities, Borders and Relationships over Time. Routledge

- Mikhailova E., 2018. Are refugees welcome to the Arctic? Perceptions of Arctic migrants at the Russian-Norwegian borderland. In Besier G., Stoklosa K. (eds.), How to Deal with Refugees? LIT Verlag, Berlin, p. 183-200

- Mikhailova E., 2018. Collaborative problem solving in cross-border context: learning from paired local communities along the Russian border. Journal of Borderlands Studies, vol. 33, $\mathrm{n}^{\circ} 3$, p. $445-464$. 